\title{
Phenomenology as Grammar
}

\author{
An Introduction
}

\author{
JESÚs PADILLA GÁLVEZ
}

This volume gathers papers which were read at the congress held at the University of Castilla-La Mancha in Toledo (Spain), in September 2007, under the general subject of phenomenology. More specifically, the congress was devoted to Wittgenstein's thoughts on phenomenology. One of the aims of the congress was to consider and examine the lasting importance of phenomenology for philosophic discussion.

The term 'Phenomenology' originated G. W. F. Hegel, for whom it was mainly an approach to philosophy that began with an exploration of that, whatever it is, which presents itself to us in conscious experience, as a means to finally grasp the absolute, logical, ontological and metaphysical spirit that is behind all phenomena. 'Phenomenology' is thus understood as the method employed in scientific philosophy. In his first major work, Phenomenology of Spirit (1807), Hegel constructed phenomenology as a representation of the "real sciences". He outlined the development of the mind through various phases, in which it first apprehends itself to the point of full development, where it is aware of itself as it is in itself. Hegel says:

"It is this process by which science in general comes about, this gradual development of knowing, that is set forth here in the Phenomenology of the Spirit. Knowing, as it is found at the start, mind in its immediate and primitive stage, is without the essential nature of mind, is sense-consciousness. To reach the stage of genuine knowledge, or produce the element where science is found-the pure conception of science itself-a long and laborious journey must be undertaken. This process towards science, as regards the content it will bring to light and the forms it will assume in the course of its progress, will not be what is primarily imagined by leading the unscientific consciousness up to the level of science: it will be something different, too, from establishing and laying the foundations of science; and anyway something else than the sort of ecstatic enthusiasm which starts straight off with absolute knowledge, as if shot out of a pistol, and makes short

Phenomenology as Grammar (Ed. Jesús Padilla Gálvez), 7-14.

(C) Ontos Verlag, Frankfurt a. M. 
work of other points of view simply by explaining that it is to take no notice of them." 1

The structure of the Phenomenology of Spirit takes roughly the form of the Bildungsroman ${ }^{2}$ and explores the nature and development of the mind. It shows how the mind evolves along a process of internal contradiction and develops from the most primitive aspect of sense-perception through all of the forms of subjective and objective mind (including art, religion, and philosophy) to absolute knowledge that comprehends this entire developmental process as part of itself. Two of the contributions in this volume deal with the earlier conception of phenomenology.

Nearly a hundred years later, the idea of phenomenology was developed in a new way. For E. Husserl phenomenology was a discipline that endeavoured to describe how the world is constituted and experienced through a series of conscious acts. E. Husserl's maxim and the nature of philosophy and philosophical method were to get back to "things in themselves" ( $\mathrm{Zu}$ den Sachen selbst) ${ }^{3}$ This expression meant both, "to the things themselves" and "let's get down to what really matters!". 4 Thus, phenomenology must describe what is given to us in immediate experience without being mediated by any kind of pre-conceptions and theoretical notions. His fundamental concept was that of intentional consciousness. Thus phenomenology describes the intentional acts that involve both, the content of consciousness and the representational objective content. E. Husserl describes

\footnotetext{
${ }^{1}$ G.W.F. Hegel, Phänomenologie des Geistes. Werke, Vol. 3. Suhrkamp, Frankfurt a. M., 1970, p. 31.

2 A Bildungsroman is a novelistic form that concentrates on the moral, psychological, social, or spiritual development and growth of the protagonist. The first novel of education is Christoph Martin Wieland's History of Agathon. Goethe's work Wilhelm Meisters Lehrjahre is mentioned as a particularly exemplary novel of education. See: Axel Honneth, Kampf um Anerkennung. Zur moralischen Grammatik sozialer Konflikte. Suhrkamp, Frankfurt a. M., 2003.

${ }^{3}$ Phenomenology is a method of describing the nature of our perceptual contact with the world. It is concerned with providing a direct description of human experience. Perception is the background of experience which guides every conscious action. The world is a field for perception, and human consciousness assigns meaning to the world. We cannot separate ourselves from our perceptions of the world.

${ }^{4}$ Lothar Eley, Transzendentale Phänomenologie und Systemtheorie der Gesellschaft. Rombach, Freiburg, 1972, 29.
} 
his position in the first edition of the Logical Investigations, ${ }^{5}$ as "descriptive psychology" and carries out a profound analysis of the intentional structures of mental acts as well as of how they are directed at real and ideal objects. The first volume of the Logical Investigations, the Prolegomena to Pure Logic, begins with a devastating criticism of psychologism, i.e., the attempt of letting the a priori validity of the laws of logic to be assimilated by psychology. ${ }^{6}$ He established a separate field for research in logic, philosophy and phenomenology, totally independently from the empirical sciences. On the other hand, phenomenology also describes the process of consciousness and the general structure of the object. He developed his method indirectly, by dealing first with specific, single problems which eventually brought him to a more systematic approach.

For Husserl all knowledge is characterised by an original given intuition (originär gebende Anschauung):

"Am Prinzip aller Prinzipien; daß jede originär gebende Anschauung eine Rechtsquelle der Erkenntnis sei, daß alles, was sich uns in der 'Intuition' originär, (sozusagen in seiner leibhaften Wirklichkeit) darbietet, einfach hinzunehmen sei als was es sich gibt, aber auch nur in den Schranken, in denen es sich da gibt, kann uns keine erdenkliche Theorie irre machen."7

This is assumed to be the immediate process of direct seeing, that is, not just the actual seeing by the senses, but the seeing as original giving consciousness (als originär gebendes Bewußtseins). This process of seeing is the actual legitimized source of any reasonable assertion. E. Husserl explicitly describes what he means by 'language'. The inherited natural language is not put into question by the transcendental $\lambda$ oyos. The unity of natural language with the language of phenomenology was never doubted. The essence of language is defined by its logicality. The phenomenological programme was aimed at determining the relation between pure grammar and pure logic. It

${ }^{5}$ Edmund Husserl, Logische Untersuchungen. Untersuchungen zur Phänomenologie und Theorie der Erkenntnis, (LU) 3 Bände. Niemeyer, Tübingen, 1993.

${ }^{6}$ Husserl, $L U, \mathrm{I}, 154 \mathrm{ff}$.

7 Edmund Husserl, Ideen zu einer reinen Phänomenologie und phänomenologischen Philosophie. Erstes Buch: Allgemeine Einführung in die reine Phänomenologie. In zwei Bänder. 1. Halbband: Text der 1.-3. Auflage; 2. Halbband: Ergänzende Texte (1912 1929). (Ideen I), (Ed. Elisabeth Schuhmann). Husserliana: Edmund Husserl Gesammelte Werke, Nijhoff, Den Haag, 1976, 51. 
was therefore conceived as a doctrine concerning the forms of meanings (Formenlehre der Bedeutungen). ${ }^{8}$ Husserl wanted to know if general statements are meaningful at all. He wanted to reveal their fallacious and paradoxical character. His main goal was to investigate the logical aprioricity of language and grammar. Therefore he analyzed the implicit (Abwesenheit) and explicit (Anwesenheit) dimensions of language. Although this reduplication is a fundamental element of phenomenology, it carries with it no ontological duplication. For example, the transcendental ego is radically different from my concrete empirical ego; nevertheless, it differs from it in nothing. The transcendental ego is not a kind of phantom of the concrete empirical ego. The difficulty for him lay in the search for a language that would enable us to describe the unspoken reduplication. Now which language could serve to give a proper account of the confrontation between the concrete empirical ego and the transcendental ego? If the ego should reflect on itself, such a language would have to take into account all elements of selfobjectification.

Some years after the publication of the Logical Investigations, Husserl made some crucial elaborations which led him to distinguish between the act of consciousness (noesis) and the phenomena at which it is directed (noemata). ' 'Noetic' refers to the intentional act of consciousness (believing, willing, hating and loving ...). 'Noematic' refers to the object or content (noema) which appears in noetic acts (respectively what is believed, wanted, hated, loved ...). What we observe is not the object as it is in itself, but rather how and inasmuch it is given in intentional acts. Knowledge of essences

\footnotetext{
${ }^{8}$ E. Husserl's German expression is "reine Formenlehre der Bedeutungen", which means literally "doctrine of the pure forms of meanings". Edmund Husserl, Alte und neue Logik. Vorlesung 1908/09. (Ed. Karl Schuhmann. Nachdruck). Husserliana: Edmund Husserl Materialien, Vol. 6, Kluwer Academic Publ., Leiden, 2003, 57 f.

9 Edmund Husserl, Ideen I, 1976. Edmund Husserl, Ideen zu einer reinen Phänomenologie und phänomenologischen Philosophie. Zweites Buch: Phänomenologische Untersuchungen zur Konstitution. (Ed. Marly Biemel). Nachdruck. Husserliana: Edmund Husserl - Gesammelte Werke, Nijhoff, Den Haag, 1991. Edmund Husserl, Ideen zu einer reinen Phänomenologie und phänomenologischen Philosophie. Drittes Buch: Die Phänomenologie und die Fundamente der Wissenschaften. (Ed. Marly Biemel). Nachdruck. Husserliana: Edmund Husserl - Gesammelte Werke, Nijhoff, Den Haag, 1971.
} 
would only be possible by "bracketing" all assumptions about the existence of an external world. Husserl calls this procedure ė $\pi 0 \chi \eta$ (epoché) or "Einklammerung". ${ }^{10}$ Husserl says:

"Durch die phänomenologische $\dot{\pi} \pi \circ \chi \eta$ reduziere ich mein natürliches menschliches Ich und mein Seelenleben - das Reich meiner psychologischen Selbsterfahrung - auf mein transzendental-phänomenologischen Selbsterfahrung."11

In a later period he would concentrate more on the ideal, essential structures of consciousness. As he wanted to exclude any hypothesis about the existence of external objects, he introduced the method of phenomenological reduction to eliminate them.

Having what has been said as a background, we can now ask: What did drag Wittgenstein into working on phenomenology? In order to understand which problems he was dealing with, we have first to have a look at the methodology he used in his approach. In this context it should be noted that, except for the terms 'phenomenology' and 'phenomenological', Wittgenstein simply did not have recourse to Husserl's specialized philosophical vocabulary. Wittgenstein's acquaintance with the history of philosophy was not particularly extent and he made little attempt to relate his investigations to the classical corpus of philosophical speculations. His knowledge of phenomenology was rather fragmentary.

For over four decades now scholars have been writing and arguing about Wittgenstein's relationship to Husserl's phenomenology. ${ }^{12}$ The German

${ }^{10}$ E. Husserl, Cartesianische Meditationen und Pariser Vorträge. Hrsg. und eingeleitet von Stephan Strasser. Nachdruck der 2. verb. Auflage. Husserliana: Edmund Husserl Gesammelte Werke, Nijhoff, Den Haag, 1991. See: Elisabeth Ströker, Das Problem der

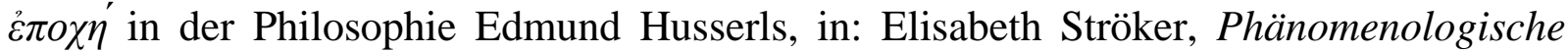
Studien, Vittorio Klostermann, Frankfurt a. M., 1987, 35-53.

${ }^{11}$ Husserl $C M, 65$.

12 C. A. van Peursen, Husserl and Wittgenstein, Philosophy and Phenomenological Research, 20, 1959, 181-197; F. C. Copelston, Wittgenstein frente a Husserl, Revista Portuguesa de Filosofía, 21, 1965, 134-149; Thomas N. Munson, Wittgenstein's Phenomenology, Philosophy and Phenomenological Research, 23:1, 1962, 37-50; Herbert Spiegelberg, The Puzzle of Wittgenstein's Phänomenologie (1929-?), American Philosophical Quarterly, 5, 1968, 244-256; Wataru Kuroda, Phenomenology and Grammar. A Consideration of the Relation Between Husserl's Logical Investigations and Wittgenstein's Later Philosophy, in: Annalecta Husserliana, 8, 1978, 89-107; Herbert 
publication of The Big Typescript in 2000 and its English translation in $2005^{13}$ represented the main impetus for a new discussion. In his "middle period" work, Wittgenstein used the headline "Phenomenology is Grammar". $\mathrm{He}$ describes his position as follows:

"The investigation of the rules of the use of our language, the recognition (Erkenntnis) of these rules, and their clearly surveyable representation amounts to (übersichtliche Darstellung), i.e. accomplishes the same thing as, what one often wants to achieve in constructing a phenomenological language." 15

This raises the question of whether it would make any sense at all to actually consider Wittgenstein a phenomenologist? Wittgenstein's own answer is not very precise: "You could say of my work that it is "phenomenology"". ${ }^{16}$ However, what kind of phenomenology could he have had in mind and what was Wittgenstein's view of the phenomenological movement? There are several controversial answers to these questions. Thus, for example, H. Reeder denies Wittgenstein to be a phenomenologist at all. ${ }^{17}$ On the other hand, Merrill and Jaakko Hintikka believe that Husserl's Logical

Spiegelberg, Wittgenstein Calls His Philosophy 'Phenomenology', Journal of the British Society for Phenomenology, 13:3, 1982, 296-299; Merrill B. Hintikka and Jaakko Hintikka, Investigating Wittgenstein. Basil Blackwell, Oxford, 1986; Nicholas F. Gier, Wittgenstein's Phenomenology Revisited, Philosophy Today, 34, 3, 1990, 273-288; Robert Alva Noe, Wittgenstein, Phenomenology and What It Makes Sense to Say, Philosophy and Phenomenological Research, 54:1, 1994, 1-42; William Boos, A Metalogical Critique of Wittgensteinian 'Phenomenology', in: Quantifiers, Questions and Quantum Physics. Essays on the Philosophy of Jaakko Hintikka (Eds. Daniel Kolak, John Symons), Springer Netherlands, New York, Berlin, 2004, 75-99.

${ }^{13}$ Ludwig Wittgenstein, The Big Typescript, (BT) in: Wiener Ausgabe (Ed. Michael Nedo), Springer, Wien, 2000; Ludwig Wittgenstein, The Big Typescript, in: Wiener Ausgabe (Ed. Michael Nedo), Zweitausendeins, Frankfurt am Main, 2003. Ludwig Wittgenstein, The Big Typescript, (Ed. and transl. by C. Grant Luckhardt and Maximilian A. E. Aue), Blackwell, Malden, MA, 2005.

${ }^{14}$ Wittgenstein $B T, 2000,295-323$ and Wittgenstein $B T$ 2005, 320e-345e.

${ }^{15}$ Wittgenstein $B T, 2000,295$ and Wittgenstein $B T$ 2005, 320e.

${ }^{16}$ M. O'C. Drury, Conversations with Wittgenstein, in: Personal Recollections of Ludwig Wittgenstein, (Ed. Rush Rhees), Rowman and Littlefield, Totowa, N. J., 1981, 131.

${ }^{17}$ Harry Reeder, Language and Experience: Description of Living Language in Husserl and Wittgenstein. University Press of America, Washington D. C., 1984. Harry Reeder, Never Was a Phenomenologist, Journal of the British Society for Phenomenology, 20:3, 1989, 49-68. 
Investigations, exerted a profound influence on Wittgenstein's philosophical development. In their view, Wittgenstein replaced intentionality as directedness by intentionality as intensionality. ${ }^{18}$ The Hintikkas believe that the headline "phenomenology is grammar" is partly directed against Husserl. ${ }^{19}$ They also point out that according to The Big Typescript phenomenological analysis is conceptual analysis and give two reasons for not applying the term "phenomenology" to Wittgenstein's later works: first, Wittgenstein's rejection of a separate "phenomenological" language went hand in hand with the development of his private language argument; secondly, he gave up the systematic science of phenomena because of his discovery of linguistic pluralism and his identification of meaning with use. H. Reeder has harshly criticized the first part of their objection. Now although Wittgenstein certainly did furnish any kind of phenomenological language, it can safely be said that he nevertheless did not give up the basic project of phenomenology. ${ }^{20}$

A serious discussion of this topic would require a description of the cornerstones and themes of Wittgenstein's phenomenology. These cornerstones can be signalled by notions like language, grammar, rule, visual space (Gesichtsraum) versus Euclidean space, minima visibilia ${ }^{21}$ and colours. All his investigations centre around these themes. However, we should not forget that without Husserl's innovative works Wittgenstein's corrections could not possibly be understood.

L. Wittgenstein's main interest takes the form of a research on language. From this perspective Husserl's questions have to be approached in a completely different way. Wittgenstein did grasp a variety of phenomenological problems ${ }^{22}$ and was interested in analysing the phenomenological language. He says:

"The investigation of the rules of the use of our language, the recognition of these rule, and their clearly surveyable representation amounts to, i.e. accomplishes the

${ }^{18}$ Merrill B. Hintikka and Jaakko Hintikka, Investigating Wittgenstein. Basil Blackwell, Oxford, 1986, p. 150.

${ }^{19}$ Hintikka and Jaakko Hintikka 1986, p. 154.

${ }^{20}$ Nicholas F. Gier, Wittgenstein's Phenomenology Revisited, Philosophy Today, 34, 3, 1990, 277.

${ }^{21}$ Jesús Padilla Gálvez, Minima visivilia, Episteme NS, 25, 2005, 53-79.

${ }^{22}$ Wittgenstein BF I 53, 23. 
same thing as, what one often wants to achieve in constructing a phenomenological language. ${ }^{23}$

His main target was the concept of the visually tangible (das Erfahrbare). He wanted to determine certain terms, statements and description in their phenomenological meaning. By characterizing phenomenology as grammar, he distinguished it from the empirical sciences. This move resembles the attempt of trying to express something about the essential. Contrary to Husserl, however, in Wittgenstein's considerations to speak about the essential boils down to speak about the rules of grammar. ${ }^{24}$ Accordingly, the essence of numbers is something that emerges from the rules of their use; the nature of the chromatic phenomena appears in the grammar of the words for colours, ${ }^{25}$ and so on. Now one of the goals of this book is precisely to bring out the similarities and discrepancies between Husserl's and Wittgenstein' stances.

The papers of the present collection were accepted by the Scientific Committee of the III. International Congress on "Transcendental Phenomenology versus Grammatical Phenomenology", held at the University of Castilla-La Mancha in Toledo in September 2007. On the occasion of this third congress, a number of acknowledgements are in order:

First, I would like to thank all those colleagues who accepted our invitation to both participate in the congress and to contribute to the book. Secondly, I am indebted to the public institutions that have financially supported the congress. On this occasion, we benefited not only from the continued and generous support of the Departments of Research and Development of the Government of Castilla-La Mancha, the Provincial Concil of Toledo, the City Council of Toledo, the University of Castilla-La Mancha and the Faculty of Law and Social Sciences in Toledo, but also from the generous support of the Alexander von Humboldt Stiftung in Bonn (Germany) and the Internationale Ludwig Wittgenstein Gesellschaft in Leipzig (Germany).

\footnotetext{
${ }^{23}$ Wittgenstein $B T, 94$.

${ }^{24}$ Wittgenstein $P U$ I, 371.

${ }^{25}$ Wittgenstein $B T, 97,310$.
} 